\title{
初代培養肝細胞を用いた肝臓のタンパク質, アミノ酸代謝と栄養
}

田 中 啓二, 市原明

徳島大学医学部酵素研究施設

\section{Nutritional and Metabolic Studies of Proteins and Amino Acids in Primary Cultured Hepatocytes}

\author{
Keiji TANAKA and Akira ICHIHARA \\ Institute for Enzyme Research, School of Medicine, University \\ of Tokushima, Tokushima 770
}

肝搭は実に多様な機能を営んでおり，またそれが多種 のホルモンで調節されている。それには血糖調節のため のクリコーゲン合成と分解, アミノ酸分解による糖新生, それに伴ら尿素形成，ほとんどの血清タンバク質の合成 と分泌, 脂質合成 (リポタンパクとして分泌)，脂質酸化 (ケトン体として放出), 胆汁形成と排泄, 解毒, グルタ チオン合成やビタミンの活性化等があり，これらがイン スリン，クルカコン，カテュラミン，糖質コルチュイ ド，甲状腺ホルモン等で調節されている。るちろん食慨 性影響む大きい。

このような複雑な肝機能の解明に全動物，灌流，切片 を用いる研究方法は限界がある。灌流法は in vivo の状 態を反映するよい実験法であるが，せいぜい1時間程度 しか肝臟は正常でない。また肝臓全体ではどの細胞の活 性を検討しているのかが明確でない。その他肝株細胞や 肝癌細胞の培盖細胞む用いられているが，これらの細胞 は汪とんど癌化して肝機能を失っているか，残存機能む 限られている。たとえばクルカゴンに応答する株細胞や トリプトファンオキシダナーゼ，セリン脱本醭素を維持 している肝癌細胞は知られていない1)。このような実験 方法のなかで，われわれが用いている成鶖ラット肝実質 細胞の初代単層培羔法は後述するごとく，すべての肝機 能を in vivo と同レベルに維持し，また各種ホルモンに よく応答する。この方法は 1969 年 Berry と Friend に よってコラゲナーぜで肝実質細胞を分散する方法として 開発され，1973 年ごろよりそれが初代培養されはじめ た。現在でも分散直後の細胞を Krebs-Ringer 溶液等で インキュベートしている報告が多くあるが，これでは長 期のホルモンの影䇺等は㭘討できないし，分散直後の細

\footnotetext{
于 770 徳島市蔵本町 3
}

胞は活性の低下や死滅細胞を含んでいるので培養により これを除外したほうがよい。初代培養といらと数種の細 胞の混在の印象を与えるか，肝実質細胞に関しては，元 来肝組織で実質細胞は $60 \%$ 程度を占めていること, 他 の細胞に比し実質細胞は数倍大きいので, 遠心分離によ り容易にほとんど完全な実質細胞のみの培養系を作るこ とができる。

この方法の詳細やそれを使ってどのような研究がされ てきたかについては，すでに多数の総説があるので2 7$)$, ここでは执むにアミノ酸とタンパク質栄養についてのみ 詳述する。

\section{1. 初代培美肝細胞の肝機能とホルモンによる調節}

われわれは成熟ラット肝実質細胞を分離すると Williams $\mathrm{E}$ 培地, $5 \%$ 仔ウシ血清, $2 \mathrm{nM}$ インスリンか 10 $\mathrm{nM}$ デキサメサゾンの培地でプラスチックシャーレに 7 $\times 10^{4}$ 細胞 $/ \mathrm{cm}^{2}$ 程度にまき， $5 \% \mathrm{CO}_{2}, 30 \% \mathrm{O}_{2}, 37^{\circ} \mathrm{C}$ で $2 \sim 3$ 時間培養する。この間に細胞はシャーレ底面に 接着, 伸展する。インスリンかデキサメサゾンは細胞の初 期生存に必須に近い。血清はファイブロネクチンでおき かえらるが8)，通常血清（必ずしも仔ウシ血清でなくと もよい）を加えるほらが生存がよい。このよらにして細 胞を定着させたら，無ホルモン，無血清培地（Williams $\mathrm{E}$ 培地のみ）にして20 時間程度培養し本実験にはいる。 これからさらに数日の実験は十分に可能である。この間 培地は毎日交換する。最初にまいた細胞の $80 \%$ 以上が 生存している（因 1)。な挊近七ト肝細胞む同様の手 技で培養できるようになり，われわれも約 10 例の経験 を持っているが形態的にラットの場合とほとんど変わら ない。 


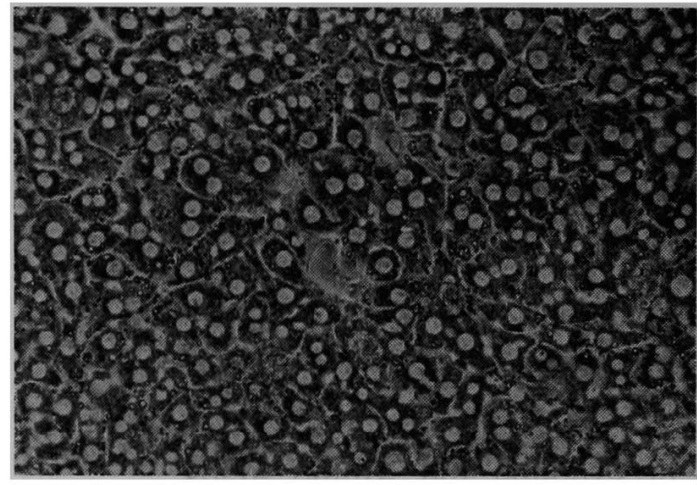

図 1.成熟ラット肝実質細胞の単層初代培養 ( 3 日目)

細胞は接着, 伸展して位相差顕微鏡で核がよく見え る。肝実質細胞以外の細胞は見当たらないし, 組織 構築もととのっている。

さてこのよらな肝細胞を用いてと゚のような生化学的機 能が研究できるかをまとめたのが表 1 である。これらは すべてわれわれの研究室で明らかにしたものであるが， もちろん他の研究室でも多くの研究がなされて扣り, わ れわれが検討していないP-450 や胆汁形成の報告もある が，紙面の制限でそれらについては上述の総説を参照さ れたい。

ここにあげた肝機能は in vivo の肝臓と同程度の活性 を示し，またそれが種々のホルモンの生理的濃度で明確 に変動する。in vivoの実験のように多くの例数を重ね, しかも不明確な差しか認められないようなことはない。

\section{2. 培地のアミノ酸組成}

従来の培地は株細胞增殖を指摽に考案されており, 果 たして正常肝細胞の培養に適しているかどらか問題があ る。しかし, この肝細胞の培湌に対する培地了ミノ酸組 成については必ずしも詳細な研究はなされておらず,一 般に細胞培養に用いられる Eagle の minimal essential medium(MEM) でも培養は可能である。しかしわれわれ がタンパク質合成を指標に検討した結果ではアミノ酸の 種類の多いWilliams E 培地（表 2) がより良好であっ たのでわれわれはこの培地を用いている。この培地は ラット肝実質細胞を初代培養するのに適した培地として 開発されたものであるが，最近は Leibovitz L-15 培地 がさらに良好な細胞を得る結果を得ている。この培地は 各種アミノ酸をその溶解度の上限まで加えて扣り, その 緩衝力で $\mathrm{pH}$ をコントロールしているので, 普通の培地 のよ5に重炭酸ソーダを加え $\mathrm{CO}_{2}$ インキュペーター中 で培養する必要はない。またほとんどの培地がグルコー スを加えているが，後述するように正常肝細胞はおもに アミノ酸, 有機酸からェネルギーを得ているのでグルコ
表 1. 初代培養肝細胞に発現する肝機能とホルモン 応答性

\begin{tabular}{|c|c|c|}
\hline 機 & 促進因子 & 阻害因子 \\
\hline アルブミン合成 ${ }^{9768)}$ & \multicolumn{2}{|l|}{ Dex, アミノ酸 } \\
\hline VLDL 合成 ${ }^{11)}$ & \multicolumn{2}{|l|}{$\begin{array}{l}\text { Ins, Dex, } \\
\text { エストラジオール, } \\
\text { Glu }\end{array}$} \\
\hline 脂肪酸合成 ${ }^{12)}$ & \multicolumn{2}{|l|}{ Ins, Dex } \\
\hline $\begin{array}{l}\text { ニレステロール } \\
\text { 合成 }{ }^{12,13)}\end{array}$ & \multicolumn{2}{|l|}{$\prime \prime \prime \prime$} \\
\hline リンゴ酸脱水素酵素 & Ins, $T_{3}$ & EGF, $c$ AMP \\
\hline
\end{tabular}

G6P脱水素酵素12) 14) Ins, EGF

グルコキナーゼ(15) ／l Glu

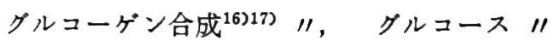

\begin{tabular}{|c|c|c|}
\hline DNA 合成 ${ }^{18) ~ 20)}$ & Ins, EGF & $\begin{array}{l}\text { Dex, J } \\
\text { ラギン }\end{array}$ \\
\hline $\begin{array}{l}\text { オルチ } \\
\text { 素18) }\end{array}$ & $\begin{array}{l}\text { Ins, EGF } \\
\text { アスパラギン }\end{array}$ & \\
\hline $\begin{array}{l}\text { チロシントランス } \\
\text { アミナーゼ21)(22) }\end{array}$ & Glu, Dex, $\beta$ & Ins, $\alpha$ \\
\hline セリン脱水酵素 ${ }^{22) ~ 24) ~}$ & $\prime \prime, " 11$, & \\
\hline $\begin{array}{c}\text { リジン-2-オキソグル } \\
\text { タル酸還元酵素 }{ }^{25)}\end{array}$ & $11, \quad 11$ & $11, \prime \prime$ \\
\hline 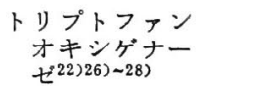 & ドリプトブーン & $\begin{array}{l}\prime \prime \\
\prime \prime\end{array}$ \\
\hline
\end{tabular}

尿素形成 ${ }^{10)} \quad$ Glu, Dex

$$
\begin{array}{ll}
\text { インスリンレセプ } & \text { Ins } \\
\text { ター16) } & \\
\text { グルカゴンレセプ } & \text { Glu } \\
\text { ター29)30) } & \\
\text { カテュラミンレヒプ } & \\
\text { ター29) 31) } & \\
\text { グリューケ゚ン分 } & \\
\text { 解(16)17>32) } & \text { Glu, } \beta
\end{array}
$$

Dex : デキサメサゾン $\left(10^{-5} \mathrm{M}\right)$, Ins : インスリン

$\left(10^{-7} \mathrm{M}\right), \mathrm{Glu}$ : グルカコ゚ン $\left(10^{-7} \mathrm{M}\right), \alpha$ : カテュ ラミン $\alpha$ 作用(フェニレフリン, $10^{-5} \mathrm{M}$ ), $\beta$ : カテュ ラミン $\beta$ 作用 (イソプロテレノール, $10^{-5} \mathrm{M}$ ), $\mathrm{T}_{3}$ : トリヨードサイロニン $\left(10^{-5} \mathrm{M}\right)$

ース添加の意味がどれほどか颎問である。グルコースは 乳酸を生じ培地 $\mathrm{pH}$ を低下させるのでガラクトースに置 き替えている培地すある。

\section{3. アミノ酸の膜透過}

肝臓はアミノ酸代謝の中心的な贜器であり，また種々 
表 2 . 培地アミノ酸組成 $(\mathrm{mg} / \mathrm{l})$

\begin{tabular}{|c|c|c|c|c|c|}
\hline & $\underset{E^{35)}}{\text { Williams }}$ & $\begin{array}{l}\text { Leibovitz } \\
\text { L-15 }\end{array}$ & Eagle MEM & Parker 199 & $\begin{array}{l}\text { Seglen } \\
\text { SMI }\end{array}$ \\
\hline L-Alanine & 900.0 & 225.0 & & 25.0 & 178 \\
\hline L-Arginine $\cdot \mathrm{HCl}$ & 60.5 & $500.0^{a)}$ & 126.4 & 70.0 & $178^{d)}$ \\
\hline L-Asparagine $\cdot \mathrm{H}_{2} \mathrm{O}$ & 20.0 & $250.0^{b)}$ & & & 661 \\
\hline L-Aspartic Acid & 30.0 & & & 30.0 & 13 \\
\hline L-Cysteine $\cdot \mathrm{HCl} \cdot \mathrm{H}_{2} \mathrm{O}$ & 58.0 & $120.0^{\mathrm{a})}$ & & 0.1 & 24 \\
\hline L-Cystine & 20.0 & & 24.0 & 20.0 & \\
\hline L-Glutamic Acid & 50.0 & & & 66.8 & 44 \\
\hline L-Glutamine & 292.3 & 300.0 & 292.3 & 100.0 & 731 \\
\hline Glutathione & 0.05 & & & 0.05 & \\
\hline Glycine & 50.0 & 200.0 & & 50.0 & 150 \\
\hline L-Histidine $\cdot \mathrm{HCl} \cdot \mathrm{H}_{2} \mathrm{O}$ & 20.3 & $250.0^{\mathrm{a})}$ & 41.9 & 21.9 & 155 \\
\hline L-Isoleucine & 50.0 & 125.0 & 52.5 & 20.0 & 79 \\
\hline L-Leucine & 75.0 & 125.0 & 52.5 & 60.0 & 328 \\
\hline L-Lysine $\cdot \mathrm{HCl}$ & 87.5 & 93.7 & 73.1 & 70.0 & 55 \\
\hline L-Methionine & 15.0 & 75.0 & 14.9 & 15.0 & 45 \\
\hline L-Phenylalanine & 25.0 & 125.0 & 33.0 & 25.0 & 330 \\
\hline L-Proline & 30.0 & & & $40.3^{c)}$ & 115 \\
\hline L-Serine & 10.0 & 200.0 & & 25.0 & 105 \\
\hline L-Threonine & 40.0 & 300.0 & 47.6 & 30.0 & 119 \\
\hline L-Tryptophan & 10.0 & 20.0 & 10.2 & 10.0 & 102 \\
\hline L-Tyrosine & 35.0 & 300.0 & 36.2 & 40.0 & 362 \\
\hline L-Valine & 50.0 & 100.0 & 46.9 & 25.0 & 117 \\
\hline
\end{tabular}

a) $2 \mathrm{H}_{2} \mathrm{O}$, b) 遊離塩基, c) ハイドロオキシプロリン $10.0 \mathrm{mg} / l$ 追加, d) 代わりにオルニチン $\mathrm{HCl} 51 \mathrm{mg} / l$ 添 加。

なホルモンの僄的器官でもあるので, この䑏器における アミノ酸輸送活性は代謝変動ととるに大きく変化する可 能性があり，この変化は生体全体のアミノ酸プールおよ びタンパク質代謝に大きく影響すると思われる。動物細 胞のアミノ酸輸送采についてはエールリッヒ腹水癌細胞 を用いたChristensen一派の研究によって確立され，そ の概念の多くが他の細胞にも適用されている。他方, 肝 細胞についてはその分離と培荃法の確立以来多くの研究 が発表され，その結果，肝細胞でも基本的な点ではェ一 ルリッヒ系との類似性が認められるすのの異なった点も 種々見いだされている36)。

\section{1) 肝綢胞のアミノ酸輸送系}

分雄および初代培盖肝細胞で現在までに確立している アミノ酸輸送系についての性質を表 3 に示した。これら は $\mathrm{Na}^{+}$依存性や輪送系に特異的なアミノ酸による拮抗 阻害の有無, むるいはその反応動力学的解析などから個 個に区別されている。ここでは個なの系の詳細について は省略して以下その特徽点についていくつか述へる。中 性アミノ酸の渝送系としては MeAIB を特異基質とする
A系が典型でこの系はおすに Ala, Serなどを輸送し,後 述するよらにホルモンによる調節や適応調節を受ける。 また MeAIB 存在下で抑制されない ASC 系は, 主とし て Ala, Ser, Cys などを輸送し, この系はその容量が 大きく生理的意義が重要とされている。他方, 分岐鎖了 ミノ酸や芳香族アミノ酸の輸送系は $\mathrm{Na}^{+}$イオンに非依 存性で,この系は低親和性高容量の $\mathrm{L}_{1}$ と高親和性・低 容量の $\mathrm{I}_{2}$ の 2 種に区別されている。

一方 His, Gln, Asn など陽イオン性アミノ酸の輸送 機構および Glu, Asp など陰イオン性フミノ酸の輸送機 構は，主として肝臓由来の細胞に特異的で他の細胞では 観察されていない。これら以外に Gly に特異的な系, Cys-Glu に特異的な $\mathrm{X} \overline{\mathrm{c}}$ 系などす肝細胞に存在する。 Lys, Arg, His に特異珄のある $\mathrm{Y}^{+}$系は正常肝細胞に は微弱にしか存在しないが，糖尿ラットの肝細胞ではそ の活性が高い。

他方, 培羡肝細胞の培地中フミノ酸濃度と細胞内遊離 アミノ酸淟度の比から個々のアミノ酸輸送量の相対的割 合を比較すると，たとえば Glu，Gly，Ala など非必須つ 
表 3、肝細胞のアミノ酸輸送系とその性質および調節

\begin{tabular}{|c|c|c|c|c|}
\hline 輸送経路 & 基質特異性 & $\begin{array}{l}\mathrm{Na}^{+}- \\
\text {依存性 }\end{array}$ & 制御機構 & 徵 \\
\hline A & $\begin{array}{l}\text { Ala, AIB } \\
\text { MeAIB }\end{array}$ & 有 & $\begin{array}{l}\text { ホルモン調節 } \\
\text { 適応調節 }\end{array}$ & 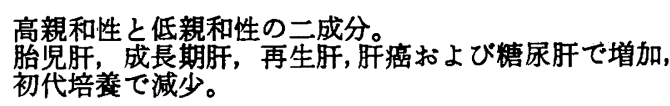 \\
\hline ASC & $\begin{array}{l}\text { Ala, Ser, Cys } \\
\text { AIB }\end{array}$ & 有 & 無 & 高容量, 肝癌で增大，初代培養で低下。 \\
\hline $\mathrm{L}_{1}$ & $\begin{array}{l}\text { Leu, Ile, Val } \\
\text { Phe, Tyr, His }\end{array}$ & 無 & 可能性有 & $\begin{array}{l}\text { 高親和性低容量, 胎児肝および肝癌に存在, 初代培盖 } \\
\text { 渵加。 }\end{array}$ \\
\hline $\mathrm{L}_{2}$ & $\begin{array}{l}\text { Leu, Ile, Val } \\
\text { Phe, Tyr, His }\end{array}$ & 無 & 無 & $\begin{array}{l}\text { 低親和性高容量, 正常肝で高く肝癌で消失，初代培養 } \\
\text { で倿。 }\end{array}$ \\
\hline Anitonic & Asp, Glu & 有/無 & 不明 & $\begin{array}{l}\mathrm{Na}^{+}-\text {依存性, 非依存性の二成分。 } \\
\text { 成熟肝で高く, 肝癌で低い。肝細胞に特異的。 }\end{array}$ \\
\hline $\mathrm{N}$ & $\begin{array}{l}\text { Gln, His, } \\
\text { Asn }\end{array}$ & 有 & 適応調節 & 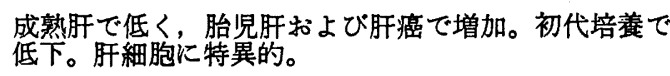 \\
\hline Gly & Gly & 有 & 不明 & 肝癌細胞および赤血球にも存在。 \\
\hline $\mathrm{Y}^{+}$ & Arg, His, Lys & 無 & ホルモン調節 & 成熟肝で低く肝癌で高い。グルカゴン投与で增加。 \\
\hline $\mathrm{X} \overline{\mathrm{c}}$ & Cys, Glu & 無 & ホルモン調節 & $\begin{array}{l}\text { 肝癌にも存在。インスリンおよびデキサメサゾンで増 } \\
\text { 加。 }\end{array}$ \\
\hline
\end{tabular}

ミノ酸では 20 50 と高い能動輸送活性を示し, 分岐鎖 アミノ酸など必須了ミノ酸では $2 \sim 3$ と低值である。こ れは細胞内の遊離フミノ酸が主としてタンパク質合成の ために利用されているのではなく，細胞内代謝のためで あることを示唆している。また正常肝細胞内の遊離フミ ノ酸プールは肝癌細胞や線維芽細胞のそれと比較すると 約 $1 / 7$ であり ${ }^{37)}$ ，このことは正常肝細胞でのアミノ酸の 代謝回転速度が著しく速いことを反映していると考えら れる。

\section{2）ホルモンによる調節}

種々のアミノ酸輸送系の中で，ホルモンによって大き く影響されるのは，主としてA系であるが ${ }^{38) ~ 50), ~ そ の う ~}$ ち親和性の高い成分 $(K m=1 \mathrm{mM})$ 飞特異的であって低 親和性の成分 $(K m=40 \mathrm{mM})$ はまったく変動しない(11)。 生理的にも前者が重要で後者が作動する状況に細胞が值 面することはほとんどない。また，A系以外にも X̄̄ 系 がインスリン怙よ゙デキサメサソンによっで51)，あるい は $\mathrm{Y}^{+}$系がグルカコンとよって誘導されることる知られ ているが(5)，ここではその効果が大きく，また解析の進 んでいるA采について述べる。

インスリンは，すべての細胞に対して同化的に作用し タンパク質合成を促進するが，同時に生理的濃度でフミ ノ酸の膜透過を増大させるる 合成が必要であり，またミクロチューブル39)やミクロフ イラメント袮細胞骨格系が関与しているらしいことる 示唆されている。他方グルカコンのアミノ酸輸送系に対 する影響は肝細胞においてとくに䫒著であり，その作用 は cyclic AMP で置換される38)41)。

この促進はタンパク質合成や核酸合成の阻害剤により
抑制されることや38)41142)，脱核した細胞では見られない ことなどから ${ }^{43)}$ ，遺伝子発現の結果と考兵られている。 また cyclic AMP で前処置した細胞の膜小胞における 輸送活性も著しく促進されるので44)，細胞膜上の輸送担 体が量的に增加していると推定される。他方グルカゴン により増大している輸送活性は，ホルモンを除去すると 半滅期 1.5 時間と急速に減少し, この低下もまたタンパ クおよび核酸合成の阻害剤によって強く抑制されること から，輸送活性を調節するタンパク質の存在が示唆され ている ${ }^{45)}$ 。

このグルカコンンとインスリンの促進効果は相加的で, 両ホルモンの作用はそのレセブターとの結合数と輸送活 性の促進と相関しており, 全レセプターの約 $20 \%$ が飽 和されると活性の増加がはじまるが(1)，両ホルモンの internalization は必要でない。さらに両者のキネティク スを見てみると、インスリンは $V_{\max }$ を上昇させグルカ

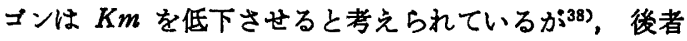
の作用がまた $V_{\max }$ の上昇であることを示唆した報告す あるい。

一方, クルココルチコイドのフミノ酸輸送に対する影 響は複雑である。このホルモンは単独では奻果がなく， グルカゴンの促進効果を增強するいわゆる permissive effect があるとされており，この両ホルモンの存在下で はA采は低い $K m$ の状態で $V_{\max }$ が増大した状態にあ $3^{38)}$ 。事実，副腎摘出したラットからの肝細胞はグルカ ヨン作用に対して competent な状態になっていないと いら結果と一致する ${ }^{36)}$ 。しかし，デキサメサソン単独で も $\mathrm{A}$ 釆の $V_{\max }$ を上昇させ，この作用はインスリンやク ルカゴンと相加的であるとの報告がある(7)一方、このホ 
ルモンが抑制的に作用するとの記戴すあり 胞でのこれらの相反する理由はまだよくわかっていな い。エピネフリンおよびノルェピネフリンなどカテコ ラミンすA輸送系の $V_{\max }$ をタンバク合成を介して增加 させる。このカテンラミンの作用は $\alpha$-adrenergic site を介して膜輸送を促進していると考えられている99)。さ SK AIB 輸送活性は細胞内 $\mathrm{Ca}^{2+}$ 灌度に强く影暗され ることも知られているので， $\alpha$-作用との関連性が注目さ れる50)。

\section{3) 適応铜節}

初代培養肝細胞の培地からアミノ酸を除去すると，輸 送系が 10 15 倍に增加してくるが，このような現象を 一般に適応調節とよんでいる52)。また絶食ラットから分 離した肝細胞の AIB 透過活性は掑食動物のものに比較 して著しく増加しているが、この場合にはグルカゴンを 介したホルモンによる影覆の可能性す否定できない。他 方,このよらな適応調節の例は，Gln のおるな輸送系で

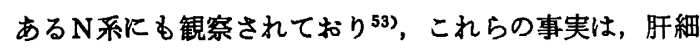
胞に批けるこのアミノ酸輸送系の增大がこのよらな生理 的条件においてとくに Ala 中 Gln からの糖新生の六進 と関係しているのかもしれない。しかしこの現象は肝外 組織細胞においても認められているので36)，糖新生以外 のより普遍的な意味があるとす考えられる。この適応誘 導はシクロヘキシミドやアクチノマイシン-Dの添加によ

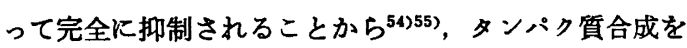
介しており，系特異的な輸送担体生合成の脱抑制と考兄 られている。この適応誘導は培地中からのすべてのアミ ノ酸の除去が必要であり，誘導される系によって輸送さ れるアミノ酸はもちろん，それ以外の系のアミノ酸の単 独投与によってる阻止される55ので，細菌に見られるよ らな“ stringent control”とは区別されているが,その 分子機構は現在不明である。

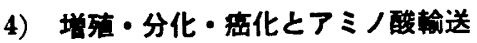

一般にフミノ酸の膜透過活性は細胞增殖と密接に関係 していることがよく知られているが，肝部分切除後の分 離肝細胞に括けるアミノ酸輸送活性を正常肝細胞と比較 するとL輸送系はほとんど变化しないにすかかわらず， $\mathrm{A}$ 輸送系の特異的な上昇が観察された ${ }^{56)}$ 。同様に成長期 ラットの初代培養肝細胞における AIB 㡏送活性は成熟 動物に比へて增加しており，このとき $\mathrm{Na}^{+} / \mathrm{K}^{+}$-ATPase 活性も高い57)。

また $\mathrm{X} \bar{c}$ 輸送系は細胞密度と関連し低密度で高く高密 度で低い ${ }^{51)}$ 。この現象は, 初代培養肝細胞が細胞密度に 依存してホルモンによる応答能などの分化型機能 と DNA 合成など細胞增殖のマーカーが相反関係にあるわ れわれの成楼と一致して興味深い,13220)。また $\mathrm{Na}^{+}$非依 存性の L輸送系のなかで， $\mathrm{L}_{1}$ 系は分離直後の細胞には
ほとんど発現していないにもかかわらず初代培養すると 增大し, 逆に $\mathrm{L}_{2}$ 系は分離細胞に多く存在し培着後に消

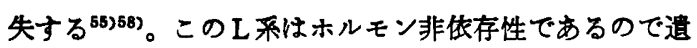
伝子発現の自律的変化と考元られ，われわれが観察した 培養によるカテコラミン $\alpha_{1}-$ レセプターの減少, $\beta$-レセ ブターの増加と類似している22229。

他方N輸送系は胎児肝細胞において高い活性が保持さ れているが59，細胞が分化して成熟肝細胞になるとほと んど完全に消失し ${ }^{55)}$ ，逆に細胞が癌化した hepatoma 細 胞ではまた強い活性が発現してくる年)。同様に $\mathrm{Y}^{+}$輸送 系も成就肝細胞ではほとんど見られないが，癌化した hepatoma では強い活性が出現している60)。これらの結 果は, 正常肝細胞と肝癌細胞ではかなり異なったアミ， 酸輸送系を獲得していることを示しているか，胎児肝細 胞之肝癌細胞との類似性を考虑すると, フミノ酸輸送系 の発現も細胞の持つ分化型機能とその增殖性との関連性 によって制御されているようである。

\section{4. 培地アミノ酸の消需 ${ }^{10)}$}

いま,ラット肝細胞をWilliams E 培地に 24 時間培 養しその消費量を比較すると，それぞれのアミノ酸によ って特徵がある10)（図 2)。Val はほとんど肝蔵で代謝さ れないことをわれわれは見いだしていたので，この培地 から消失したVal は肝タンパクの合成にすべて使われた と考える。これを基礎にして肝タンパク質に含まれる各 フミノ酸の量を多い順に並べ消費したそれぞれのアミノ 酸と此較すると，ほとんどの非必須了ミノ酸はタンパク 合成に消費されたと考えるよりはるかに多く消費されて いる。ことに Glu, Ala, Gly, Asp, Arg の消費は大きい。 肝臟のアルギナーセ活性は非常に強く, 培着開始後数時 間で培地 Arg は完全に消費され，それに匹適する Orn を形成している。これはその尿素形成量からすらかがわ れる。Gly の消費が非常に大きいのは意外で,このアミ ノ酸がその解裂酳素によって完全分解されているのか, 2 分子で 1 分子の Ser を合成したのか明らかでない。 Gly の完全分解はエネルギー産生といらより，2 位目の 炭素がラトラヒドロヨウ酸にはいって $\mathrm{C}_{1}$-ニニットの形 成として重要なのかもしれない。これと関連してSerの 消費の少ないことも意外である。Ser が糖新生に役立っ ているか否か議論が多いが，この結果から見ると糖新 生条件のグルカコン存在下でも消費が大きくない（典型 的栯原フミノ酸である Ala 中 Gin ではクルカゴン存在 下消費が大きくなっている)。このように消費が非常に大 きい Gln, Ala, Asp の大部分は糖新生のほらに用いられ たと考えられる。事実この系でフミノ酸からの糖新生を 見ると(図 3)，Ala，Asp，Glu，Gin, Proは有意義に糖 を形成し（培地のクルコース量を測る）またグルカコ 
Change in amino acid concentration ( $\mu \mathrm{M}$ in $24 \mathrm{hr}$ )

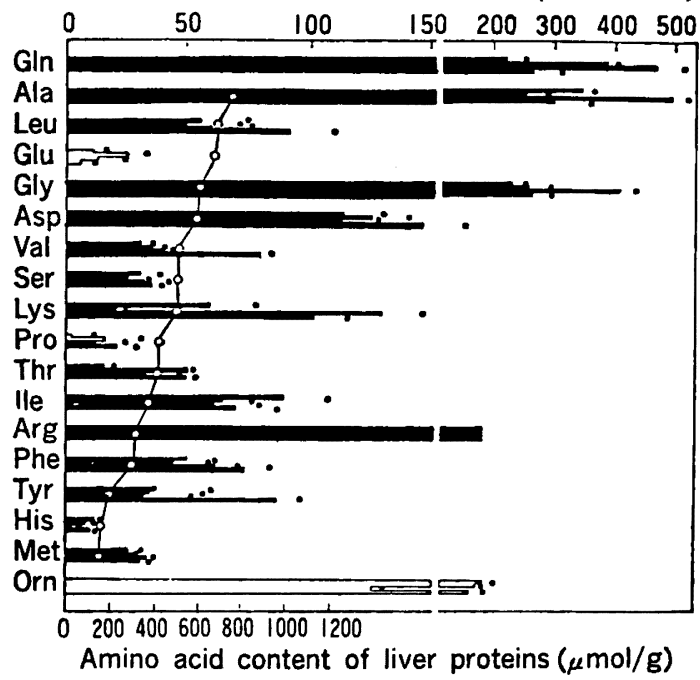

図 2、肝細胞の24時間のアミノ酸

消費，1 1 カムは 4 本のサブカラムからなり，上か らホルモンなし，インスリン(1 $\mu \mathrm{M})$ ，グルカコン(1

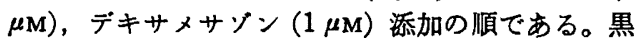
点は SE., 白点は肝タンパク質に含まれる平均アミ ノ酸量, 白カラムは形成量を示す。

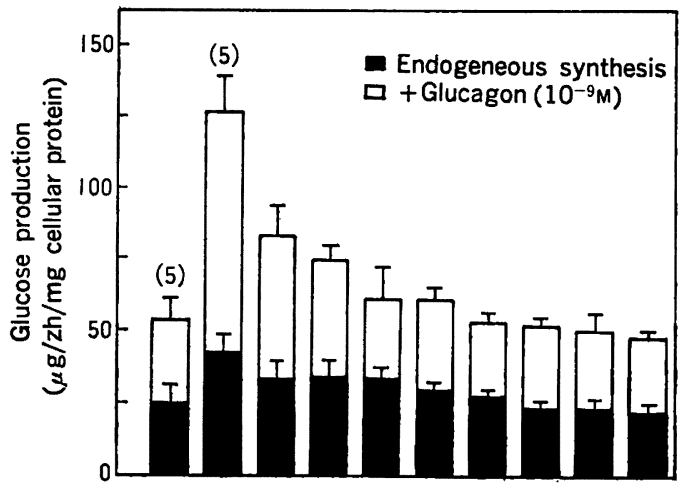

Amino acid HSS Ala Asp Glu Gln Pro Ser Gly Lys Leu $\begin{array}{lllllllllll}\text { cont }(\mathrm{mm}) & \text { I.01 } & 0.26 & 0.34 & 2.0 & 0.26 & 0.10 & 0.67 & 0.48 & 0.57\end{array}$

図 3. 培盖肝細胞のアミノ酸からの糖新生とグルカ ゴンによる促進, HSS : Hanks 塩類溶液。

ンにより促進されているが, Ser, Gly, Lys, Leu（後 二者はケトン原性であるから糖新生にはつながらない対 照実験的のものである）ははとんど糖新生には使われて いない。Glu は消費よりむしろ放出されている。これ は Gln に由来するもので Glu の消費を上まわる形成に よる。

概して必須フミノ酸の消費は少なく，タンパク合成に おもに使われたと考えてよい。しかしグルカゴンやデキ サメサゾンを加えた場合には，消費が大きくなってい る。これは必須アミノ酸でる，このようなホルモン条件

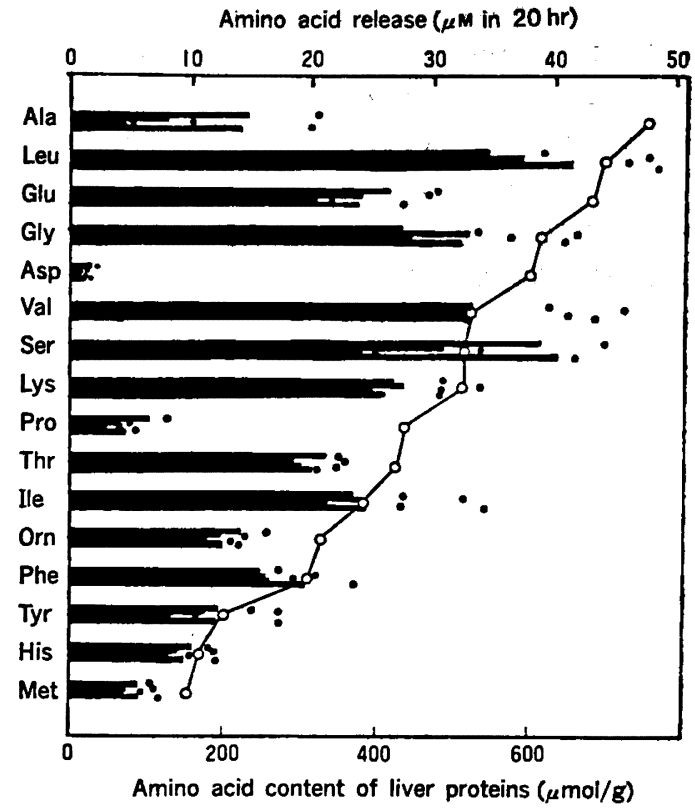

図 4.培盖肝細胞を塩類溶液に 24 時間おいたとき の培地へのアミノ酸の出現 ${ }^{10)}$

シンボルは図 2 と同じ。

（生体では糖尿病，飢餓，高タンパク食）では, 糖産生 が増加するためと思われ, 事実これらのアミノ酸を分解 する酵素がこの条件下誘導される（表 1 ）。

\section{5. 肝細胞タンパク分解による培地へのアミノ酸放出}

次に, 培地からてミノ酸を完全に拔いて, 塩類溶液中 で肝細胞のタンパク代謝がどらなるかを見たのが図4で ある。培地にアミノ酸がないと肝細胞からアミノ酸が出 てくるが，因 2 と同じく䀒平均タンパク含有アミノ酸量 と比較すると，大部分のアミノ酸はこのパターンによく 一致している。すなわち，肝タンパク質の分解によって 出てきたアミノ酸が，そのまま放出したことを意味す る。細胞は異化状態となっている。しかし，このパター ンに合わない Ala, Gln, Asp, Pro 等は, エネルギー 産生に使われたと思われる。この場合す Glyの消費と七 リンの形成を合わせ考えてす，Gly から Ser が形成さ れている可能性は少ない。Arg はまったく検出できず, これは Orn に変化しているので, これを Arg のとこ ろに直き替えると，やはりパターンにほほ合っている。

このように初代培美肝細胞培地のアミノ酸注度变化か ら肝タンパク質, アミノ酸の動態をよくらかがことが できる。

\section{6. 肝細胞のエネルギー代到とアミノ酸}

従来すべての培養細胞のェネルギー産生は，解桾によ 
ると考えられていた。実祭，いままで用いられた種々の 培萑株細胞は，100\% クルュースに依存している。しか し Bissell らは, 初代培養肝細胞はグルュースの利用が 非常に少なく，またその $30 \%$ を完全酸化しているとい $5^{333}$ 。同じ培養肝細胞でる株化された BRL や肝癌由来 の HTC は，いずれるわずか肝機能を維持しているが， ほとんどそのエネルギー産生を解糖に依存している。こ のように実質細胞由来でも培養株化したもの（継代培盖 可能なもの）は明らかに正常な代謝からはずれてきてい る。元来肝臟は脳への血糖供給を担当している臟器で, 血糖を消費する臓器ではない。このことは，この初代培 美肝細胞を用いたクリコーゲン代謝の調節から見ても支 持され，インスリンよりる高濃度のグルコースとグルカ ゴンでより強く調節されている ${ }^{17) 。 こ の こ と か ら も こ の ~}$ 初代培養采が正常な代謝を営んでいることがわかる。

それでは肝䁍のエネルギー原はおすに何かということ になるが,これは必ずしも明らかでない。脂肪酸といら考 えもあるか，分離旰細胞のタンパク質合成促進といら指

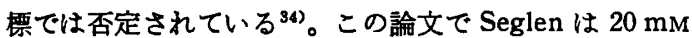
のビルビン酸が有効であるとしている。この肝細胞は分 離直後の短時間のタンパ 合成を指標にしているので長 期の培養にそのまま当てはまらないが参考になる。ピル ビン酸は糖と乳酸からも供給されるが，上述の糖の利用 がこの細胞であまりないことを考えれば，ピルビン酸は Ala，Ser，Cys，Trp K由来することになるが，われわ れの図 2 の結果や量から考えると，Ala がその主役であ ると考えられる。事実培着肝細胞の DNA 合成にもピル ビン酸は促進作用のあることが報告されているし ${ }^{61162)}$, われわれる確認している。このほか TCA サイクルの中 間体も有効であるので，いずれも酸化的りン酸化により ATP を生産しているようである。すべてのフミノ酸の 分解は究極的に TCA サイクルにはいるから，図2に示 したてミノ酸の消費は糖新生への利用のみならず，肝細 胞自身のエネルギー原にもなっているといえるが消費量 の何\%に当たるかは不明である。タンパク質合成を指標 に見ると種々のフミノ酸が促進するが，ピルビン酸を加 えるとその效果は見られなくなる34。またその逆の場合 はピルビン酸の効果が消失する。いずれにしても，この 肝細胞が相当量のアミノ酸をエネルギー源にしていると 思われ，なかであ Ala， Gln，Asp 等がその主なるるの と思われるが，詳細は今後の研究に待たねばならない。

\section{7. 䀒細胞㻥殖とアミノ酸の影需}

このような分化機能を維持した細胞は一般的に培喰系 で増殖しないと考えられてきた。事実，通常の培菱法で は，この肝細胞もまったく増殖しないし DNA 合成も見 られない。しかし最近，われわれを含めいくつかの研究
表 4. 肝細胞機能の密度依存性調節

\begin{tabular}{|c|c|c|c|c|}
\hline \multirow[b]{2}{*}{ 肝 機 能 } & \multirow[b]{2}{*}{ 促進因子 } & \multicolumn{3}{|c|}{ 活性 $(\%)^{*}$} \\
\hline & & $\left(\begin{array}{c}25 \\
\times 10^{3}\end{array}\right.$ & $\begin{array}{r}75 \\
\text { 紐胞 }\end{array}$ & $\begin{array}{r}125 \\
\left.\mathrm{~cm}^{2}\right)\end{array}$ \\
\hline DNA 合成 & Ins + EGF & 100 & 36 & 5 \\
\hline アミノ酸吸収 & Ins & 100 & 67 & 42 \\
\hline \multicolumn{2}{|c|}{ 細胞内タンパク質合成 } & 100 & 84 & 52 \\
\hline \multicolumn{2}{|l|}{ 血清タンパク質合成 } & 100 & 100 & 100 \\
\hline \multicolumn{2}{|l|}{ コレステロール合成 } & 100 & 75 & 37 \\
\hline \multicolumn{4}{|l|}{ 酵素誘道 } & 100 \\
\hline G6P 脱水素䤃素 & Ins + EGF & 100 & 38 & 23 \\
\hline \multicolumn{2}{|c|}{ リンゴ酸脱水素酵素Ins $+T_{3}$} & 34 & 50 & 100 \\
\hline TAT & Dex & 11 & 47 & 100 \\
\hline セリン脱我酵素 & Dex +Glu & 13 & 44 & 100 \\
\hline
\end{tabular}

* 示された細胞密度で 1 日培養後ホルモン添加,さ らに $1 \sim 2$ 日後活性を測定した。

室がこの初代培養肝細胞を増殖させることに成功した。 その条件は, インスリン $\left(10^{-8} \mathrm{M}\right)$, epidermal growth factor (EGF) $(20 \mathrm{ng} / \mathrm{ml})$ を低細胞密度 $\left(3 \sim 5 \times 10^{4}\right.$ 細 胞 $\left./ \mathrm{cm}^{2}\right)$ に添加することで, この条件にすると 15 時間 くらいで分裂を開始する ${ }^{19}$ ，この細胞密度依存性增殖は 他の種々の活性にも影䇾を持ち表 4 のごとく，增殖に関 係した活性は低細胞密度で培養したとき增加するし，逆 に肝特異的分化機能は高細胞密度で増加する ${ }^{20)}$ 。

このらちタンパク質, フミノ酸代謝に関保するるのと してはアミノ酸吸収,タンパク質合成, アミノ酸分解醉素 活性等があるが，前二者は低細胞密度，後者は高細胞密 度で増加する。このことから正常では細胞は接触が密で 静止し分化機能が発現しているが ( $G_{0}$ 期)，肝障害（あ るいは旰部分切除でも）がおこると細胞接触が眯になり (この報告も多くある)， 細胞は細胞周期にはいり， $\left(G_{1}\right.$ 期)，インスリン， EGF や血清中の增殖因子に上り分裂 増殖が促進される。この間成熱機能の発現は抑制されて いる。細胞は $2 \sim 3$ 回分裂すると接触が再び密になり， 再び $\mathrm{G}_{0}$ 期にもどる。これが正常の肝再生である。この 細胞接触による調節をする因子を細胞膜から抽出した

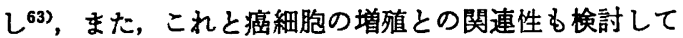
いるが(6)，この総説の範囲をこえるので省略する。

さてこの培着肝細胞の增殖を検討中, ある培地 (Williams E, McCoy A-5, Ham F12) では DNA 合成か インスリンと EGF 存在下十分おこるのに, 他の培地 (Eagle MEM, Dulbecco 改善 MEM, Leibovitz L-15) ではまったくおこらないことを見いたしただ)。これらの 培地のアミノ酸を比較して後者に共通して久けているの 
はPro である（表 2)。そこで後者の培地にPro を30 $\mathrm{mg} / l$ 添加すると果たして DNA 合成が扰こった。

DNA 合成への Pro の必要性の機構はコラーゲン合成 の材料のためであることは，コラーゲン合成の阻害剤を 種々用いると，たとえProを添加してす DNA 合成か阻 害されることかららかがえるか，興味あることは，これ らの実験をあらかじめ培養シャーレをコラーゲンでコー トした上に細胞を培湌しても見られるので，外からのコ ラーゲンの添加は無効で, 肝細胞が合成するコラーゲン， が重要であると思われる。コラーゲンには I 〜 型の あることが知られているが，初代培翊肝細胞は I 型 ${ }^{66)}$ と 四型(7) コラーゲンを合成することが知られている。どの タイプのコラーゲンが DNA 合成に必要か，またどのよ らな機構によるのか等について今後研究を進めねばなら ない。Proはこの培養肝細胞である程度合成されている と思われるが，増殖といら細胞の大きな活動のときには 内因的量のみでは足りないのではないかと思われる。

細胞増殖にはポリアミン（プトレスシン，スペミジ ン, スペルミン) が関係していると考えられ，この初発 反応を触媒するオルニチン眖炭酸酵素が増殖に先行して 著明に增加するか，この培養肝細胞でも増殖を促進する よらな条件でこの醭素が急激に誘導される18)。この醭素 は半減期が非常に短く, 肝蔵では約 10 分といわれてい るが, 種々のアミノ酸がこの䣼素を安定化し, 半減期を 延長させる（すなわち量が增加する）。われわれの細胞 に種々のアミノ酸を加えて検討した結果では, Asp,

Pro, Gly, Gln, Ser などがその効果を強く示した。ま た逆に Gln, Asn は DNA 合成を阻害した。Ala も阻 害すると報告されている61)。しかし，これらアミノ酸の 影響が実際in vivo の肝再生にどのように関係している のかは不明である。

\section{8. 培地了ミノ酸によるタンパク質生合成の調節}

動物を無タンパク食で飼育した場合, 肝蔵の固有タン パク質の合成はほとんぞ影響されないが，フルブミンや フィブリノーゲンなどの血墏タンパク質の分泌活性は急 速に低下することが知られている。これはそのよらな生 理条件下では, 肝タンパク質合成のための積極的な適応 がおこっていると解されているが，その機構は不明であ った。そこで著者らは，初代培檨肝細胞の培地てミノ酸 濃度を変化させ, 細胞内拉よび分泌タンパク質の生合成 に対する影響を調べた ${ }^{68)}$ 。図 5 に示すよらに，培地中か らフミノ酸を除去すると，血墏タンパク質の合成速度は 急速に低下するが，細胞内タンパク質の生合成は比較的 安定に維持された後，徐々に低下しはじめる。このとき 再びアミノ酸を添加すると，両活性とも可逆的に回復す る。このことはフミノ酸欠乏による細胞の損伤ではない

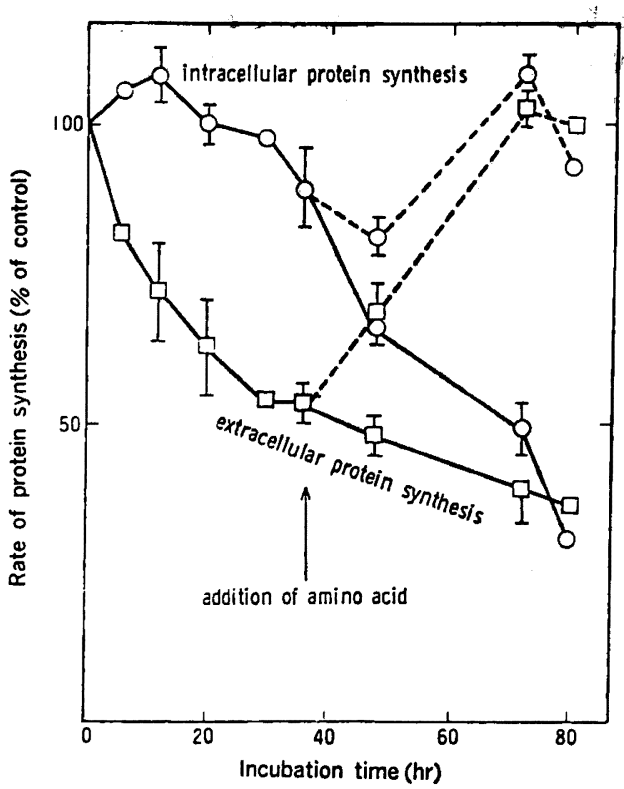

困 5. 初代培着肝細胞のタンパク質合成に対する培 地了ミノ酸除去の効果 ${ }^{68)}$

○ 細胞内タンパク質， ロ 細胞外タンパク質

2 日間培盖した肝細胞をつミノ酸を含まない培地で 培養後の各時間でタンパク質合成を測定。タンパク 質合成は ${ }^{14} \mathrm{C}-$-ロシンを含む完全培地で 3 時間標識 した後，細胞内および培地中へ分泌されたタンパク 質の放射活性を測定し，完全培地で培養した値の\% で標示した。肝細胞は合成した全タンパク質の30 $50 \%$ を分泌する。

破線は矢印の 36 時間に批いてアミノ酸を再添加し た後のタンパク質合成の回復効果を調べたものであ る。

ことを示している。アミノ酸無添加培地で培養した肝細 胞の微細構造を電子頭微鏡で観察すると, 粗面小胞体膜 結合型ポリソームの特異的な崩壊が観察されると同時 に, 多数の autophasic vacuoles が出現しタンパク質分 解活性の充進が示唆された。さらにこの変化は血清アル ブミンについても免疫学的方法により確かめられたが, このとき細胞内には合成されたアルブミンの蓄積は観察 されなかったので，この変化は，血漿タンパク質の細胞 内輸送活性の低下ではなく, その合成活性の特異的な抑 制によることが示唆された。そこで培地中アミノ酸浱度 を種々に変動させた後のこれらタンパク質合成活性の変 化を見ると, 図6(B)に示すように培地了ミノ酸総瀑度が 2 3 mM 以下になると,血漿タンパク質合成の特異的な 抑制が打こり,このフミノ酸源度は血中フミノ酸濃度に 近似しているのでこのような in vitro の調節が生理的意 義を有しているるのと推定された。さて興味あることは 培地了ミノ酸瀑度が低下するにすかかわらず，細胞内タ ンパク質合成が維持されていることであり，これはタン 


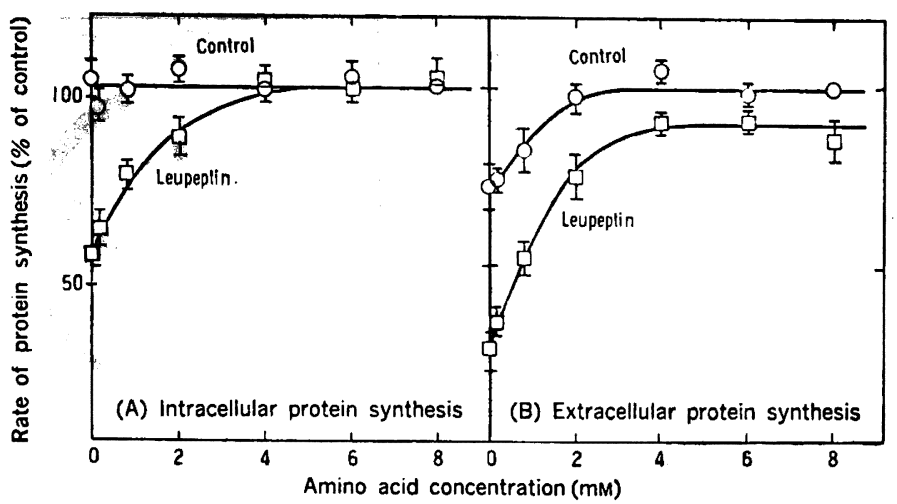

目 6.タンパク質合成に対する培地フミノ酸の効果とロイペプチンの影響68

種々の濃度の培地フミノ酸で肝細胞を12時間培養後細胞内 $(\mathrm{A})$ および細胞 外(B)タンパク質の生合成を測定。

この培着中ロイペプチン $(50 \mu \mathrm{g} / \mathrm{ml})$ を含む場合（口）と対照 (O)。数值

は $8 \mathrm{mM}$ アミノ酸を含む完全培地での生合成速度の％で標示した。

ハク質分解活性の妄進との関連性が予想される。後述す るよらに，低栄着状態に批けるタンパク質分解の亢進は 主としてライッソームの機能によることが示唆されてい るので，この働きを抑制させるため，ライソン゙ーム． SH-プロテフーゼの阻害剤であるロイベプチンの影響を 調べた。この阻害剤を添加し，ライソゾームを介したタ ンパク質分解を强く抑制すると，培地中アミノ酸濃度が 高い場合にはタンパク質合成には無影響であるが，培地 フミノ酸濃度を低下させた場合には，この状態で維持し ていた細胞内タンパク質生合成が低下してゆくことがわ

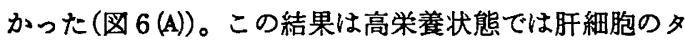
ンハクク質分解は低く, 生合成に対する役割が小さいか, 細胞外フミノ酸瀑度が低い場合には，ライソゾーム機能 の六進によって生じたアミノ酸が積極的にタンパク質合 成のために再利用されることを示唆している。しかる， この場合, このアミノ酸は細胞内タンパク質合成を維持 するために選択的に再利用されるといらことを示唆して いる。いい換えれば，細胞内タンパク質および分泌性タ ンハク質生合成のための前駆体フミノ酸プールが両者で 異なり，ラインソームを介して生じた遊離フミノ酸プー ルの流れに方向性があることを示唆している（図 7)。

以上の結果は肝細胞が細胞外了ミノ酸濃度に適応して 細胞内タンパク質および血奬タンパク質の合成比率を調 節していることを示唆するとともに，その作用部位が細 胞内フミノ酸プールの compartmentation にあることを 示している。さらにタンパク質分解によって生じたフミ ノ酸再利用の程度がその細胞外濃度によって変動する可 能性をも意味していることになりこのことは肝䯈タン バク質代謝回転の生理的重要珄をる示唆している。

これらの推定は, 肝㼨における遊離型および膜結合型 ポリソームへのアミノ酸の取り込み速度が異なっている
という現象や，全動物でのアミノ酸の再利用がタンパク 質の摄取レベルによって変動するといら in vivo の知見 などとも合致するよらである。

このことはまた，肝細胞タンパク栄養の経済学ともい らべき視点からも興味深い。肝臓はほとんどの血清タン パク質を合成分泌して他組織の役に立っているが，自己 の栄養状態が覀くなれば，まず他組織のためのタンバク 質合成を抑制し，自己に必要なタンパク質合成に専念す るようになるともいえる。

\section{9. 肝細胞空素バランスとアミノ酸}

肝細胞タンパク質の代謝回転の動態を検索するため, 培地中アミノ酸, 尿素およびアンモニアの総窒素変化量 から細胞当たりのN-バランスを計算する方法がある ${ }^{699}$ 。 たとえば肝細胞を低アミノ酸培地で培盖すると，培地中 へのアミノ酸の遊離とわずかではあるが尿素怙よびアン モニアの放出が認められ, 負の N-バランスを示す。他 方, 高アミノ酸培地で培養した場合には，尿素の形成は 增加するが，培地了ミノ酸の消費が著しく高まるので， 結果として正の N-バランスを示す。この場合, N-バラ ンスは遊離窒素の変化量であり,タンパク質結合 Nにつ いては計算していないので，それが負や正の値を示すこ とは, 細胞タンパク質の分解六進や生合成の增加を意味 していることになり, 結局, このパラメーターはタンパ ク質代謝回転の動態を示していることになる。そして， 細胞外了ミノ酸浀度の増加化伴って N-ハiランスが上昇 するのはタンパク質生合成の促進と分解の抑制の結果で あり,この場合, 高い正值は肝細胞タンパク質の增量で はなく，主として血漿タンパク質生合成の促進と推定さ れる。そこで，培地中アミノ酸濃度を変化させた場合の $\mathrm{N}$-バランスとホルモンの影锌についての結果を図8に 


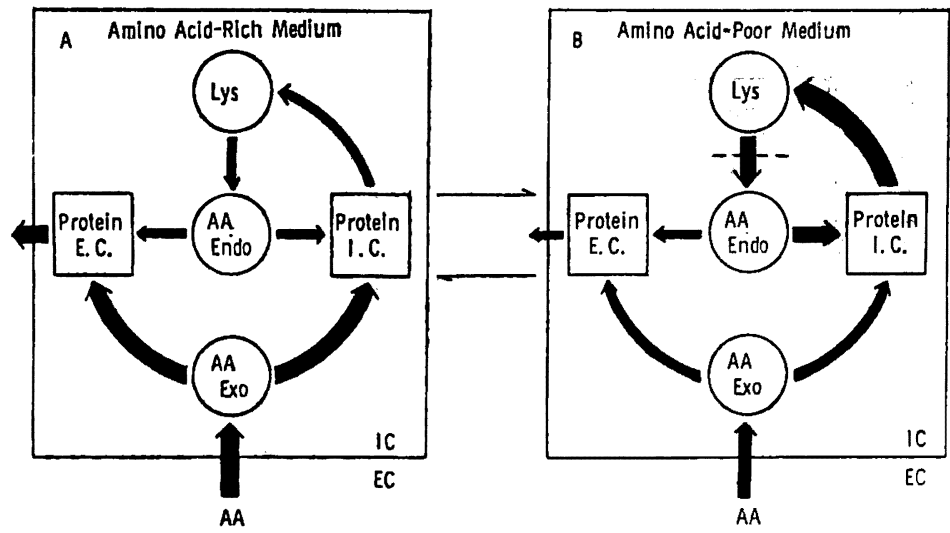

図 7. 肝細胞におけるタンパク質生合成のための前駆体アミノ酸プール の不均一性を示すモデル

$\mathrm{AA}:$ : ノ酸, I.C. : 細胞内, E.C. : 細胞外, AA Endo : 細胞内タンハ ク質の分解によって生じたてミノ酸に由来する前駆体プール, AA Exo： 細胞外から輸送されたアミノ酸に由来する前駆体プール，Lys：ライソ ゾーム, 点線はプロテフーゼ阻害㓮によるフミノ酸遊離の阻害を示す。

示した ${ }^{10)}$ 。N-バランスは培地アミノ酸総濃度が $1 \mathrm{mM}$ 前後で負から正へ逆転するが，これは， aminoacyl一 tRNA 合成酵素の $K m$ が $\mu_{\mathrm{M}}$ 程度とかなり小さいこと や，フミノ酸輸送系の誘導 ${ }^{52254)}$ 牳よびタンパク質分解の 抑制等が関係していると思われる。またホルモンの影響 を見てみると、インスリンは正の促進に，またグルカゴ ンは負の促進に作用し両者は拮抗したが， N-バランス が負から正へ変化する転換点のアミノ酸濃度には大きく 影響しなかった。またクルカゴンはアミノ酸無添加でも 異化的に作用したが，インスリンの同化作用にはアミノ 酸の存在が必須で, 無添加の場合には効果的な作用を示 さなかった。そして，クルカゴンの作用は主として尿素 合成の促進であり,インスリンの作用は顕著なつミノ酸 の消費として観察された。これらの結果は両ホルモンが タンバク質の合成および分解比対する作用が相反してい ることと一致した ${ }^{70)}$ 。

一方，灌流肝におけるタンパク質合成を正常レベルに 維持するには血中アミノ酸濃度の 5 10 倍量が必要であ り，インスリンがこの要求量を低下させる作用があり， この細胞レベルの結果と一致したが，この方法ではタン パク質代謝を同化的な状態に長期間維持することはきわ めて困難である。しかしながら初代培養肝細胞の場合に は，低浱度の培地つミノ酸によく応答し，またホルモン の直接的な影缽も見られるので，これらの代謝研究に有 効である。

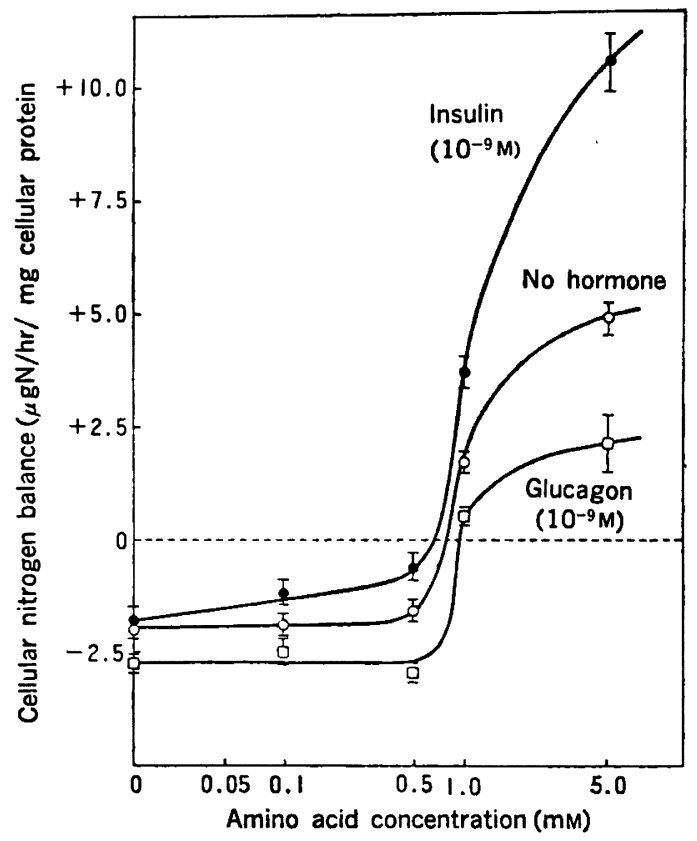

図 8. 肝細胞のN-ハラランスに対する培地アミノ酸 とホルモンの影整

培羞肝細胞を種々のアミノ酸およびホルモンを含む 培地で 30 分保温後 $10 \%$ トリク口ロ酢酸上清の N 量をアミノ酸，尿素およびアンモニアを個別に定星 し，その総和を計算し Nーバランスとした。 正, 負の值はおのおの Nの取り込みと放出を示して いる。 
表 5.肝細胞のタンパク質分解に対する栄養状態と $\mathrm{Ca}^{2+}$ の影䇾

\begin{tabular}{|c|c|c|c|c|}
\hline \multirow{3}{*}{ Addition } & \multicolumn{4}{|c|}{ Cellular protein breakdown $(\% / \mathrm{h})$} \\
\hline & \multicolumn{2}{|c|}{ Anabolic state } & \multicolumn{2}{|c|}{ Catabolic state } \\
\hline & Short-lived & Long-lived & Short-lived & Long-lived \\
\hline$-\mathrm{Ca}^{2+}$ & $10.21 \pm 1.65$ & $1.37 \pm 0.07$ & $10.63 \pm 0.88$ & $3.34 \pm 0.10$ \\
\hline$+\mathrm{Ca}^{2+}$ & $9.91 \pm 1.25$ & $1.36 \pm 0.08$ & $10.85 \pm 1.14$ & $3.10 \pm 0.06$ \\
\hline$-\mathrm{Ca}^{2+}+\mathrm{EGTA}$ & $10.50 \pm 1.66$ & $1.51 \pm 0.06$ & $10.98 \pm 1.68$ & $1.74 \pm 0.14$ \\
\hline$+\mathrm{Ca}^{2+}+\mathrm{EGTA}$ & $9.72+0.85$ & $1.34 \pm 0.10$ & $10.59 \pm 1.35$ & $3.22 \pm 0.12$ \\
\hline
\end{tabular}

Anabolic state : アミノ酸添加+インスリン $\left(10^{-8} \mathrm{M}\right)$ Catabolic state : アミノ酸除去十グルカゴン $\left(10^{-7} \mathrm{M}\right)$ Short-lived（半減期の短いタンパク質）: ${ }^{3} \mathrm{H}-$ ロインンで 1 時間標識 Long-lived (半減期の長いタンパク質) : ${ }^{3} \mathrm{H}-$ ロインンで 30 時間標識 ${ }^{3} \mathrm{H}-$ ロイシンを含む培地で上記の時間タンパク質を標識後, ロイシン $(10 \mathrm{mM})$ を含む培地で洗浄し， 2 種の培 地で放射性アミノ酸の遊離を測定。このとき $\mathrm{Ca}^{2+}(5 \mathrm{mM})$ および EGTA $(0.2 \mathrm{mM})$ の存在, 非存在下でこれ らの影響を検討した。分解時間は Short-lived, Long-lived で各 1，4 時間。

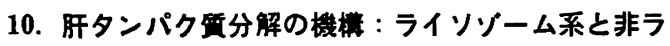 イソソーム系}

現在，細胞内に拈けるタンハクク質は，ライソソーム系 と非ラインソーム系の二種の異なった経路によって分解 されることが知られている。さらに細胞内タンパク質 は, 比較的半減期の短い成分と半減期の長い安定な成分 の 2 種に大別でき，主として前者は代謝調節に関係する よらな機能タンパク質, また後者は細胞の構成タンパク 質からなっていると推定されている。肝膈においては後 者が大部分を占め, 両者は放射性アミノ酸によるタンパ ク質の標識時間を選択することによって，個別に測定す ることができる。そして興味ある現象の一つは, 細胞を 異化状態,すなわちアミノ酸の除去やグルカコン処理に 置くと，半隇期の長いタンパク質の分解が数倍六進する が, この促進状態はアミノ酸やインスリンの添加で抑制 される ${ }^{11}$ 。他方, 半減期の短いタンパク質はこれら細胞 外環境の変化にまったく応答しない(表 5 )。そこで,こ れらのタンパ質の分解に対するライソソームの役割を 検討するためには，この細胞内顆粒の機能を阻害する必 要がある。ライソソームは酸性ブロテフーゼであるカテ プシンDとSH-プロテフーゼであるカテプシン B, H,L, T 等の 2 群のエンドプロテアーゼを含んでいるので, これ らの特異的な阻害剤であるべブスタチンとロイベプチン の影響を調べるとベブスタチンよりロイベブチンのほう がタンパク分解に対する抑制効果が強く、これは酸性ブ ロテアーセよりる SH-プロテフーゼ群のほらがより重 要な意義を有していることを示唆している（表 6 )。ま た，両者の同時存在下では常に相加的な阻害効果が認め られたので，両ブロテフーゼは細胞内において異なった 基質を分解していることが予想され，機能分担のあるこ

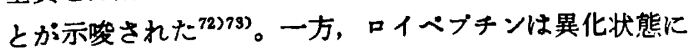

おけるタンパク質分解の充進を強く、ほぼ正常レベルま で抑制するが，同化状態では，10〜20\%のわずかの阻害 しか認められない。

すなわち，通常のタンバク質分解に対するライソゾー 么の役割は小さく, 全活性の $20 \%$ にも満たないが, 異 化状態において充進した分解活性が，ほとんどこの顆粒 の機能に依存していることを示している。同様な結論は ライソソーム内の $\mathrm{pH}$ を上昇させることによって，その 機能を阻害するよらな物質, $\mathrm{NH}_{4} \mathrm{Cl}$, クロロキンの処置 によっても得られている ${ }^{7174)}$ 。さらに電子顕微鏡の観察 によっても高栄盖状態では autophagy が少なく低栄盖 状態では autophagic vacuoles の著しい増加が 観察さ $れ^{68)}$, この vacuoles の出現, 消失の半減期は䄪 15 分と きわめて速い ${ }^{75)}$ 。また，このライソソーム機能を介した タンパク質分解の亢進は, シクローキシミドの添加で完 全抑制されることから，タンパク質合成を必要としてい ることを示唆しているか，その機作は不明である。

さらにこの autophagic/lysosomal 経路によるタンパ ク質分解活性の增減は細胞外了ミノ酸濃度に依存し,な かでも肝細胞では Trp, Phe, Leu, Asn, Gin, His, Tyr などによって顕著に抑制されることが知られてい る $^{\text {(1)76)。 }}$

一方, これらラインゾームの阻害剤のいずれす半減期 の短いタンパク質の分解に対してはその栄養状態の変化 にかかわらず，まったく影響しないので，これらのタン パク質の分解にはライソソームがほとんど寄与していな いことを示唆している77)。

以上の上5に, ライソジーム系のタンパク質分解経路 が細胞外アミノ酸のレペルで調節されており, インスリ ンやグルガンなどのホルモンが細胞内アミノ酸プール の制御に関与していることは，すでに 四 $7,8 て ゙$ 示した 
表 6. 正常および異常タンパク質の分解に対する各種阻害郕の影辢

\begin{tabular}{lccccc}
\hline \hline \multirow{2}{*}{ Addition } & \multicolumn{4}{c}{ Degradative rate $(\% / \mathrm{h})$} \\
\cline { 2 - 3 } & \multicolumn{2}{c}{ Normal proteins } & & \multicolumn{2}{c}{ Abnormal proteins } \\
\cline { 2 - 3 } \cline { 6 - 7 } & Anabolic state & Catabolic state & & Anabolic state & Catabolic state \\
\hline Control & $1.52 \pm 0.14$ & $3.19 \pm 0.27$ & & $8.36 \pm 0.70$ & $9.12 \pm 1.35$ \\
Pepstatin $(50 \mu \mathrm{g} / \mathrm{ml})$ & $1.50 \pm 0.11$ & $2.93 \pm 0.25$ & & $8.52 \pm 0.72$ & $9.01 \pm 1.55$ \\
Leupeptin $(50 \mu \mathrm{g} / \mathrm{ml})$ & $1.20 \pm 0.09$ & $1.65 \pm 0.15$ & & $8.67 \pm 0.91$ & $8.56 \pm 1.15$ \\
Cycloheximide $(10 \mu \mathrm{M})$ & $1.35 \pm 0.13$ & $1.77 \pm 0.08$ & & $8.52 \pm 0.87$ & $8.47 \pm 1.02$ \\
DNP $(0.2 \mathrm{mM})+\mathrm{DG}(20 \mathrm{mM})$ & $0.54 \pm 0.08$ & $1.05 \pm 0.23$ & & $2.92 \pm 0.27$ & $2.85 \pm 0.31$ \\
\hline \hline
\end{tabular}

実験方法は表 5 の Long-lived protein の場合と同じ。

DNP (2, 4-dinitrophenol); DG (2-deoxyglucose)

Abnormal protein の分解は L-Phe のかわりに DL-p-fluoroPhe (10 mM) の存在下で ${ }^{3} \mathrm{H}-$ ロイシンを 30 時間標 識させたもので normal は L-Phe $(0.2 \mathrm{mM})$ を含んでいる。

タンパク質合成の前駆体プールや $\mathrm{N}$-バランスが培地フ

ミノ酸によって調節されているといらモデルを強く支持 している。

最近，代謝調節の因子としてとくに注目されている $\mathrm{Ca}^{2+}$ が，タンパク質の分解にも関与していることが示 唆されており,この $\mathrm{Ca}^{2+}$ の機能について培着肝細胞で 検討した（表 5 )。C $\mathrm{Ca}^{2+}$ のキレーターである EGTAは， 低栄養状態で充進した半減期の長いタンパク質の分解の みを強く㧕制し, 高栄養状態のものや半減期の短いタン ハク質の分解には洼とんど影響しないことから, $\mathrm{Ca}^{2+}$ が ラインデーム経路に関係していることが示唆された。他 方，肝細胞は種々の物質を endocytosis し，とくにその 形質膜表面にあるホルモン-や糖タンパク質などの receptor-mediated endocytosis によって取り込まれたタン パク質は，大部分がラインソームで異化されることが知 られているが，これらの分解には $\mathrm{Ca}^{2+}$ がまったく作用 していないことから ${ }^{78)}$, heterophagy と autophagy で は同しラインゾームが関与するもののその機構が異なっ ていることを示唆している。すなわち $\mathrm{Ca}^{2+}$ は autophagosome と一次ラインソームとの融合に関与してい るらしく, heterophagosome に対しては無関係のよう である。このことは 3-methyladenine が内因性タンハ ク質のラインソームを介した分解を特異的に抑制し細胞 に取り込まれたタンパクには関係しないといら報告にも 一致している79)。

一方，ライソソーム系に比較すると非ライソソーム系 の機構については，現在まだ十分解析されていないか， 最近，この経路の重要性が指適されつつある。タンパク 質分解の生理的意義の一つに異常タンパク質の急速な分 解排除がある。突然変異や生合成過程での誤翻訳および 酸化などの化学修飾によって生じた異常タンパク質の細 胞内での蓄積は，細胞にとって有害であり，これらをで
きるかぎり速やかに分解排除する機構が存在する。表 6 に示したように, アミノ酸のアナログ存在下で合成させ た異常タンパク質は，正常タンパク質の $5 \sim 6$ 倍の速さ で分解される。この分解速度はラインソーム機能のいず れの阻害剤によっても影響されないことと同時に，細胞 外環境の変化にもまったく応答しないこと ${ }^{77)}$ ながらこ の過程にはライソジームがまったく寄与していないと推 定される。他方、赤血球ゴーストを用いた細胞融合の手 法を利用して,変性タンパク質を直接細胞質に注入して, その分解様式を解析すると，同様にラインゾーム機能の 抑制とは無関係であり，主として細胞質で独自に分解さ れていることが示唆された ${ }^{80) ~ 822 。 ~}$

他方，タンパク質分解の興味あるもら一つの点は，そ のエネルギー依存性である。最初この機構はラインソー ムへの基質の取り込みに必要なエネルギーとか，ライン ゾームの $\mathrm{pH}$ を酸性に保つためとも考えられた。しか し, 表 6 に示すよらにライソゾーム非依存性と考えられ る異常タンパク質の分解む DNP と DG の共存下で細 胞内 ATP レベルを低下させると，顕著に抑制されるこ とや、ラインソームが存在しない細菌に拈けるタンパク 質分解も同様にエネルギー依存性であることなどから， このエネルギー依存性が非ライソゾームタンバク質分解 系の一つの特改となっている。この ATP 依存性タンパ ク分解機構として分子量 8,500のニビキチン (ubiquitin）が見いだされた ${ }^{83)}$ 。のタンバク質は基質タンバク 質に共有結合しこれが分解系にはいるシクナルルはる というすのでありニビキチンの活性化に ATP のエネル ギーを要求すると考えられている。いい换えればエネル ギーは基質の共有結合による修飾の段階に必要とされる 点で，まったく新しい考えである。しかし著者らは基質 特異性 ${ }^{80)}$ ，阻害剂特異性 ${ }^{85}$ およびヌクレオタイド特異 性 ${ }^{86)}$ からエネルギー依存性はニビキチンとは異なった過 
表 7. 細胞内エンドプロテフーゼの種類と性状

\begin{tabular}{|c|c|c|c|}
\hline プロテアーゼ & 分類 & $\stackrel{\text { 分 }}{\left.\mathrm{Mr} \times 10^{-3}\right)}$ & 性 \\
\hline \multicolumn{4}{|l|}{ ライソソーム系 } \\
\hline カテプシン $\mathrm{D}$ & 酸性 & $42-45$ & $\begin{array}{l}\text { 変性へモグロビンを } \mathrm{pH} 3.5 \text { で分解, ペプスタチンで阻 } \\
\text { 害年) }\end{array}$ \\
\hline カテプシン B & SH- & $24-29$ & ジペプチジルアミノペプチダーゼの強い活性を示す88) \\
\hline カテプシン $\mathrm{H}$ & SH- & $26-28$ & $\begin{array}{l}\text { エンドペプチダーゼ活性は弱く，高いフミノペブチダー } \\
\text { ゼ活性を示す89) }\end{array}$ \\
\hline カテプシン $\mathrm{L}$ & SH- & $22-24$ & 変性タンパク質に対する広い基質特異性 ${ }^{90)}$ \\
\hline カテプシン $\mathrm{T}$ & SH- & $33-35$ & $\underset{\substack{\text { チロ } \\
\text { 換1) }}}{ }$ \\
\hline \multicolumn{4}{|l|}{ 非ライソソーム系（細胞質） } \\
\hline $\mathrm{Ca}^{2+}$ 依存性プロテアーゼ & SH- & 110 & $\begin{array}{l}\mathrm{Ca}^{2+} \text { 要求性の異なった } 2 \text { 種の酵素が存在 } \\
\end{array}$ \\
\hline 高分子量プロテアーゼ & セリン & 850 & $\begin{array}{l}\text { 不活性型-活性型の相互転換, 複合活性部位を同一分子 } \\
\text { 内に有する多重機能酵素933 }\end{array}$ \\
\hline ATP 依存性プロテアーゼ & セリン & 450 & $\begin{array}{l}\text { 酵素活性の発現に ATP の加水分解が必要94) } \\
\text { 細菌および肝ミトコンドリアに存在 } \\
\text { (5) }\end{array}$ \\
\hline
\end{tabular}

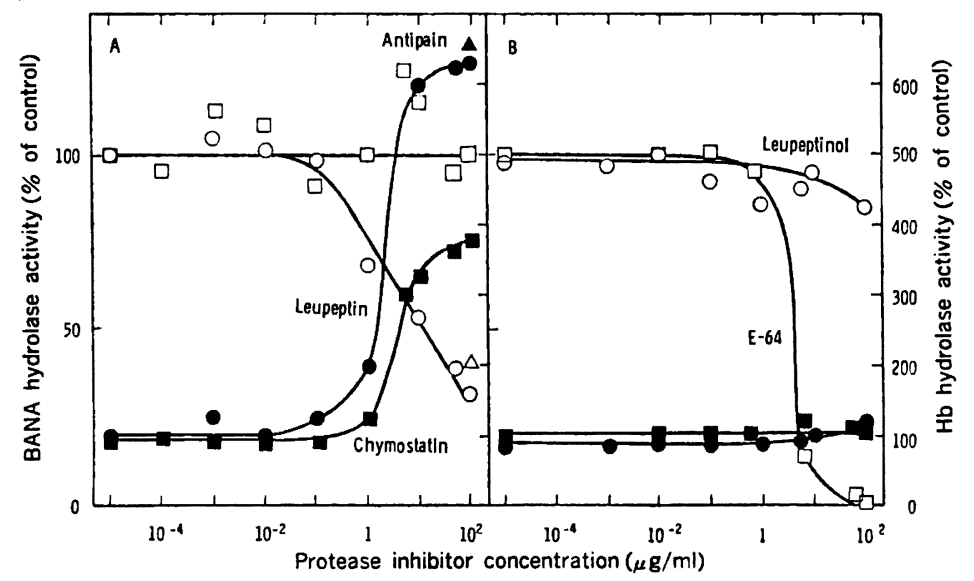

図 9.肝細胞の $\mathrm{Hb}$ および BANA 分解活性に及ぼす各種プロテフーゼ 阻害剤の影響

種々の濃度の各種阻害剤を含む培地で 1 日培盖した肝細胞を凍 結 融解 後, 遠心してその上清の $\mathrm{pH} 5$ に拈けてプテアーゼ活性を測定。 黒ぬり印はへモグロビン (Hb) 分解活性を示し, 白抜きはBz-Arg- $\beta$ NA (BANA) 分解活性を示した。

数値はおのおの, 阻害剤を添加しない場合の活性の\%で標示。

程にも必要であることを示した。しかし，肝細胞など哺 乳禹物の細胞では，エネルギー依存性を示すにすかかわ らずこれらの無細胞系ではATP にまったく応答しない ので，現在また明らかにされていないような制御機構が 存在するのかもしれない。

表 7 にはこのライソソーム系および非ライソソーム系 に圆係すると思われるェンドブロテアーゼをまとめたの
でその詳細は文献を参照されたい。

最後に初代培竓肝細胞を用いた研究の過程で，われわ

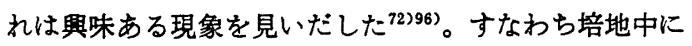
ロイペプチンを長時間添加しておくと, へモグロビンを 基質とし，ペプスタチン非感受性酸性プロテフーゼ活性 が顕著に増加してくることである。不活性型ロイペプチ ンであるロイペプチノールにこの誘導作用がまったく見 
られないことから，その発現にはその阻害活性が必要で あること，またこの誘導がシクロへキシミド，ッニカマ イシンの共存下で抑制されることなども見いだした。さ らに, アンチパインやキモスタチンにす同様な効果が認 められるにすかかわらず，SH-プロテフーゼの特異的な 阻害剂である E-64 にはその効果が認められないことか ら(図 9),この誘導にはロイペプチンなどのセリンプロ テフーゼの阻害活性が関与していることが推定された。

同様な誘導はロイペプチンをラットに投与することに よっても観察され，電気泳動的に単一な標品として精製

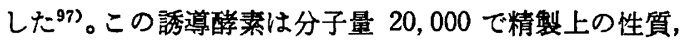
基質，阻害剤の特異性はカテプシンLにきわめて類似し た性質を有しているが，その安定性，醭素タンパク質分解 活性では明らかに異なっている。また，他のカテブシン B,H,T,D などとも区別できる。この醳素がカテプシンL の誘導体である可能性は否定できない。あるいは，その ターンオーバー速度が短いため，通常では見いだされず にいたものが，ロイペプチンなどによってその分解が抑 制された結果，蓄積してきたとも考えられるか，この醅 素の生理的意義や誘導機構の解明は今後の問題である。

しかしこのよらな代謝阻害剤を生体に与えた場合に は，この上らな予期せ姓体の反応がおこることを考え ると，医療への応用にはよほど注意しなければならな い。

\section{おわりに}

以上初代培養肝細胞を用いたタンパク質, アミノ酸栄 養, 代謝の研究の現状を総説したが,この研究法は in vivo の肝機能をそのまま in vitro に再現していると考 えてよく，そのため非常に明瞭な結果が期待できる。し かる in vivo や灌流実験では困難なホルモン, フミノ酸 の長期的影響，増殖による变化等を検討することができ る。これらの成果は臨床的肝切除, 肝炎, 肝硬変, 肝癌 の成因や治療への応用も可能であり，また食品添加物や 薬剤の肝䯈への影響についても直接的な解答を与えるの で, 近い将来の応用範囲の広がりが期待される。

\section{文献}

1）中村敏一，市原 明：蛋白質 核酸 醭素， 23 , 1272 (1978)

2）田中啓二, 市原 明：蛋白質 核酸 酵素，23， 1259 (1978)

3）中村敏一, 青山和司, 市原 明: 蛋白質 核酸 醉 素, 別冊 No. 24, 図説動物実験手技手法 (井上 正, 松本一彦編)， 55 (1981), 共立出版（東京）

4) Ichihara, A., Nakamura, T., Tanaka, K. : Mol. Cell. Biochem., 43, 145 (1982)

5) Borek, C., Williams, G.M. (編) : Ann. N.Y. Acad. Sci., 349, 1 (1980)

6) Harris, R.H. and Cornell, N.W. (編) : Isola- tion, Characterization and Use of Hepatocytes, (1983), Elsevier (Amsterdam)

7) Guguen-Guillouzo, C. and Guillouzo, A. : Mol. Cell. Biochem., 53/54, 35 (1983)

8) Horiuchi, Y., Nakamura, T. and Ichihara, A.: J. Biochem., 92, 1985 (1982)

9) Tanaka, K., Sato, M., Tomita, Y. and Ichihara, A. : J. Biochem., 84, 937 (1978)

10) Tanaka, K., Kishi, K. and Ichihara, A. : J. Biochem., 86, 863 (1979)

11) 吉本勝彦, 中村敏一: 最新医学, 37, 833 (1982)

12) Nakamura, T., Yoshimoto, K., Aoyama, K., Ichihara, A. : J. Biochem., 91, 681 (1982)

13) Yoshimoto, K., Nakamura, T. and Ichihara, A. : J. Biol. Chem., 258, 12355 (1983)

14) Yoshimoto, K., Nakamura, T. and Ichihara, A. : Biochim. Biophys. Acta, 741, 143 (1983)

15) Nakamura, T., Aoyama, K. and Ichihara, A.: Biochem. Biophys. Res. Commun., 91, 515 (1979)

16) Kato, S., Nakamura, T. and Ichihara, A. : $J$. Biochem., 92, 699 (1982)

17) Nakamura, T., Kato, S. and Ichihara, A.: $J$. Biochem., 95, 1691 (1984)

18) Tomita, Y., Nakamura, T. and Ichihara, A.: Exp. Cell Res., 135, 363 (1981)

19) Nakamura, T., Tomita, Y. and Ichihara, A.: J. Biochem., 94, 1029 (1983)

20) Nakamura, T., Yoshimoto, K., Nakayama, Y., Tomita, Y. and Ichihara, A. : Proc. Natl. Acad. Sci. U.S.A., 80, 7229 (1983)

21) Nakamura, T., Noda, C., and Ichihara, A. : Biochem. Biophys. Res. Commun., 99, 775 (1981)

22) Noda, C., Nakamura, T. and Ichihara, A. : J. Biol. Chem., 258, 1520 (1983)

23) Noda, C., Shinjyo, F., Nakamura, T. and Ichihara, A. : J. Biochem., 93, 1677 (1983)

24) Noda, C., Tomomura, M., Nakamura, T. and Ichihara, A. : J. Biochem., 95, 37 (1984)

25) Shinno, H., Noda, C., Tanaka, K. and Ichihara, A. : Biochim. Biophys. Acta, 633, 310 (1980)

26) Nakamura, T., Shinno, H. and Ichihara, A.: J. Biol. Chem., 255, 7533 (1980)

27) Nakamura, T., Aoyama, K., Tomomura, A. and Ichihara, A. : Biochim. Biophys Acta, 678, 91 (1981)

28) Niimi, S., Nakamura, T., Nawa, K. and Ichihara, A.: J. Biochem., 94, 1697 (1983)

29) Nakamura, T., Tomomura, A., Kato, S., Noda, C. and Ichihara, A. : J. Biochem., 96, 127 (1984)

30) Noda, C., Shinjyo, F., Tomomura, A., Kato, S., Nakamura, T. and Ichihara, A.: J. Biol. Chem., 259, 7747 (1984)

31) Nakamura, T., Tomomura, A., Noda, C., Shimoji, M. and Ichihara, A.: J. Biol. Chem., 258, 9283 (1983)

32) Tomomura, A., Nakamura, T. and Ichihara, A. : Biochem. Biophys. Res. Commun., 97, 1276 (1980)

33) Bissell, D.M., Levine, G.A. and Bissell, M.J.: Am. J. Physiol., 234, C 122 (1978)

34) Schwartze, P.E., Solheim, A.E. and Seglen, 
P.O. : In Vitro, 18, 43 (1982)

35) Williams, G.M., Bermudez, E., San, H.R.C. and Goldblott, P.J. : In Vitro, 14, 824 (1978)

36) Kilberg, M.S. : J. Membr. Biol., 69, 1 (1982)

37) White, M.F. and Christensen, H.N. : J. Biol. Chem., 257, 4450 (1982)

38) Kletzien, R.F., Pariza, M.W., Becher, J.E. and Potter, V.R. : J. Cell. Physiol., 89, 641 (1976)

39) Prentki, M., Crettaz, M., Jearenaud, B. : J. Biol. Chem., 256, 433 (1981)

40) Mak, W.W.N. and Pitot, H.C. : Biochem. Biophys. Res. Commun., 98, 203 (1981)

41) Fehlmann, M., LeCam, A. and Frey, C. : J. Biol. Chem., 254, 10431 (1979)

42) Edmondson, J.W. and Lumerg, L. : Biochem. Biophys. Res. Commun., 96, 61 (1980)

43) Crettaz, M., Kahn, C.R. and Fehlmann, M. : J. Cell. Physiol., 115, 186 (1983)

44) Samson, M. and Fehlmann, M. : Biochim. Biophys. Acta, 687, 35 (1982)

45) Handlogten, M.E. and Kilberg, M.S. : J. Biol. Chem., 259, 3519 (1984)

46) Sips, H.J., Gren, A.K. and Tager, J.M. : FEBS Lett., 119, 271 (1980)

47) LeCam, A. and Frey, C. : Endocrinology, 102, 379 (1978)

48) Bonney, R.J. and Maley, F. : Gene Expression and Carcinogenesis in Cultured Liver (Gerschenson, L.E. and Thompson, E.B. eds.), 24 (1975), Academic Press (New York)

49) Pariza, M.W., Butcher, F.R., Becker, J.E. and Potter, U.R. : Proc. Natl. Acad. Sci. U.S. A., 74, 234 (1977)

50) Kelley, D.S., Evanson, T. and Potter, V.R.: Proc. Natl. Acad. Sci., U.S.A., 77, 5953(1980)

51) Takada, A. and Bannai, S.: J. Biol. Chem., 259, 2441 (1984)

52) Kelley, O.S. and Potter, V.R. : J. Biol. Chem., 253, 9009 (1978)

53) Vadgama, J.V. and Christensen, H.N. : J. Biol. Chem., 258, 6422 (1983)

54) Fehlmann, M., LeCam, A., Kitabgi, P., Rey, J.-F. and Freychet, P. : J. Biol. Chem., 254, 401 (1979)

55) Handlogten, M.E., Kilberg, M.S. and Christensen, H.N. : J. Biol. Chem., 257, 345 (1982)

56) LeCam, A., Rey, J.-F., Fehlmann, M., Kitabgi, P. and Freychet, P. : Am. J. Physiol., 236(6) E 594 (1979)

57) Bellemann, P. and Potter, V.R. : Ann. N.Y. Acad. Sci., 349, 385 (1980)

58) Weissbach, L., Handlogten, M.E., Christensen, H.N. and Kilberg, M.S. : J. Biol. Chem., 257, 12006 (1982)

59) Kilberg, M.S., Handlogten, M.E. and Christensen, H.N. : J. Biol. Chem., 255, 4011(1980)

60) White, M.F. and Christensen, H.N. : J. Biol. Chem., 257, 4450 (1982)

61) McGowan, J.A., Bucher, N.L.R. : In Vitro, 19, 159 (1983)

62) Hasegawa, K. and Koga, M. : Biomed. Res., 2, 217 (1981)

63) Nakamura, T., Nakayama, Y. and Ichihara, A. : J. Biol. Chem., 259, 8056 (1984)
64) Nakamura, T., Nakayama, Y., Teramoto, H., Nawa, K. and Ichihara, A. : Proc. Natl. Acad. Sci. U.S.A., 81 (1984) (in press)

65) Nakamura, T., Teramoto, H., Tomita, Y., Ichihara, A. : Biochem. Biophys. Res. Commun., 122,884 (1984)

66) Konomi, H., Hata, R., Sano, J., Sunada, H. and Nagai, Y. : Biomed. Res., 3, 341 (1982)

67) Tseng, S.C.G., Lee, P.C., Ells, P.F., Bissell, D.M., Smuckler, E.A. and Stern, R. : Hepato$\log y, 2,13$ (1982)

68) Tanaka, K. and Ichihara, A. : J. Biochem., 94, 1339 (1983)

69) Seglen, P.O. : Biochim. Biophys. Acta, 496, 182 (1977)

70) Hopgood, M.F. and Ballard, F.J. : Protein Degradation in Health and Disease (Ciba Foundation Symposium 75), 205 (1980), Excepta Medica (Amsterdam)

71) Hopgood, M.F., Clark, M.G. and Ballard, F.J. : Biochemistry, 164, 399 (1977)

72) Tanaka, K., Ikegaki, N. and Ichihara, A. : Arch. Biochem. Biophys., 208, 296 (1981)

73) Ward, W.F., Chua, B.L., Li, J.B., Morgan, H.E. and Mortimore, E. : Biochem. Biophys. Res. Commun., 87, 92 (1979)

74) Grinde, B. and Seglen, P.O. : Biochim. Biophys. Acta, 632, 73 (1980)

75) Mortimore, G.E. : Nutr. Rev., 40, 1 (1982)

76) Seglen, P.O., Gorden, P.B. and Poli, A. : Biochim. Biophys. Acta, 630, 103 (1980)

77) Neff, N.T., DeMartina, G.N., and Goldberg, A.L. : J. Cell. Physiol., 101, 439 (1979)

78) Grinde, B. : Biochem. J., 216, 529 (1983)

79) Gordon, P.B. and Seglen, P.O. : Arch. Biochem. Biophys., 217, 282 (1982)

80) Bigelow, S., Hough, R. and Rechsteiner, M.: Cell, 25, 83 (1981)

81) Rote, K.V. and Rechsteiner, M. : J. Cell. Physiol., 116, 103 (1983)

82) Katznelsen, D. and Kulka, R.G. : J. Biol. Chem., 258, 9597 (1983)

83) Herchko, A. and Ciechanover, A. : Ann. Rev. Biochem., 51, 335 (1984)

84) Tanaka, K., Waxman, L. and Goldberg, A.L. : J. Cell. Biol., 96, 1580 (1983)

85) Tanaka, K., Waxman, L. and Goldberg, A.L. : J. Biol. Chem. 259, 2803 (1984)

86) Tanaka, K., Waxman, L. and Goldberg, A.L. : Cell (in press)

87) Barrett, A.J. : Protein Degradation in Health and Disease (Evered, D. and Whelam, J., eds.), 37(1980), Elsevier (Amsterdam)

88) Towatari, T., Kawabata, Y., Katunuma, N. : Eur. J. Biochem., 102, 279 (1979)

89) Herschko, H., Langner, J. Wiederanders, B., Ansorge, SiBohley, D. and Hanson, H. : Acta Biol. Med. Ger., 36, 185 (1977)

90) Herschko, H., Langner, J., Wiederanders, B., Ansorge, S. and Bohley, P. : Eur. J. Biochem. 74, 293 (1972)

91) Gohda, E. and Pitot, H.C. : J. Biol. Chem., 256, 2567 (1983)

92) Murachi, T. : TIB S, 8, 167 (1983)

93) Tanaka, K., Waxman, L. and Goldberg, A.L. : 
(in press)

94) Waxman, L. and Goldberg, A.L. : Proc. Natl. Acad. Sci. U.S.A., 79, 4883 (1982)

95) Desautels, M. and Goldberg, A.L. : J. Biol. Chem., 257, 4187 (1982)

96) Tanaka, K., Ikegaki, N. and Ichihara, A. :
Biochem. Biophys. Res. Commun., 91, 102 (1979)

97) Tanaka, K., Ikegaki, N. and Ichihara, A. : J. Biol. Chem., 259, 5932 (1984)

(昭和 59 年 7 月 23 日受理) 